\title{
Hepatitis C Virus Epitope Immunodominance and B Cell Repertoire Diversity
}

\author{
Nicholas A. Brasher ${ }^{1,2}{ }^{1}$, Anurag Adhikari ${ }^{1,2,3}$, Andrew R. Lloyd ${ }^{2}{ }^{\oplus}$, Nicodemus Tedla ${ }^{1}$ \\ and Rowena A. Bull 1,2,*(i) \\ 1 Faculty of Medicine, School of Medical Sciences, UNSW Sydney, Sydney, NSW 2052, Australia; \\ nbrasher@kirby.unsw.edu.au (N.A.B.); aadhikari@kirby.unsw.edu.au (A.A.); N.Tedla@unsw.edu.au (N.T.) \\ 2 The Kirby Institute, Faculty of Medicine, UNSW Sydney, Sydney, NSW 2052, Australia; a.lloyd@unsw.edu.au \\ 3 Department of Infection and Immunology, Kathmandu Research Institute for Biological Sciences, \\ Lalitpur 44700, Nepal \\ * Correspondence: r.bull@unsw.edu.au
}

check for updates

Citation: Brasher, N.A.; Adhikari, A.; Lloyd, A.R.; Tedla, N.; Bull, R.A. Hepatitis C Virus Epitope Immunodominance and B Cell Repertoire Diversity. Viruses 2021, 13, 983. https://doi.org/10.3390/ v13060983

Academic Editor: Thomas Fuerst

Received: 28 April 2021

Accepted: 20 May 2021

Published: 25 May 2021

Publisher's Note: MDPI stays neutral with regard to jurisdictional claims in published maps and institutional affiliations.

Copyright: (c) 2021 by the authors. Licensee MDPI, Basel, Switzerland. This article is an open access article distributed under the terms and conditions of the Creative Commons Attribution (CC BY) license (https:/ / creativecommons.org/licenses/by/ $4.0 /)$.

\begin{abstract}
Despite the advent of effective, curative treatments for hepatitis $C$ virus (HCV), a preventative vaccine remains essential for the global elimination of HCV. It is now clear that the induction of broadly neutralising antibodies (bNAbs) is essential for the rational design of such a vaccine. This review details the current understanding of epitopes on the HCV envelope, characterising the potency, breadth and immunodominance of antibodies induced against these epitopes, as well as describing the interactions between B-cell receptors and HCV infection, with a particular focus on $\mathrm{bNAb}$ heavy and light chain variable gene usage. Additionally, we consider the importance of a public repertoire for antibodies against $\mathrm{HCV}$, compiling current knowledge and suggesting that further research in this area may be critical to the rational design of an effective HCV vaccine.
\end{abstract}

Keywords: hepatitis $\mathrm{C}$ virus; human monoclonal antibodies; neutralising antibodies; antigenic domains; epitope mapping; immunodominance; HCV-BCR interactions; public antibody repertoire; vaccine development

\section{Introduction}

Globally, it is estimated that over 71 million people are chronically infected with hepatitis C virus (HCV), with an annual disease-specific mortality of approximately 400,000 due to the complications of cirrhosis, liver failure, and hepatocellular carcinoma [1]. While treatment with direct-acting antiviral (DAA) drugs are highly curative, they remain costly, and the health infrastructure to deliver these treatments worldwide is poorly developed. As such, the development of a preventative vaccine against HCV remains an important focus for infectious disease research - a fact that is highlighted in the World Health Organisation's 15-year hepatitis C elimination plan [2].

Over the past three decades of HCV research, it has become clear that the induction of broadly neutralising antibodies (bNAbs) which target conserved epitopes on the viral envelope is essential for the rational design of an effective HCV vaccine. An ideal vaccine is not likely to confer absolute protection, but would improve the natural clearance rate of $25 \%$ (with the remaining 75\% developing persistent, chronic infection) [3]. The identification and analysis of the protective capacity of each antibody $(\mathrm{Ab})$ and their specific epitope targets on the viral envelope would allow the prediction of the capacity to reliably clear infection.

Whilst it is important to understand the epitope-binding sites of protective anti-HCV Abs, the B-cell receptor (BCR) characteristics that form the Ab paratope (i.e., the antigenbinding site) should not be overlooked. The characterisation of BCR gene usage, with a particular focus on the variable gene segment and complementarity-determining regions (CDRs), would allow the identification of the distinct $\mathrm{Ab}$ features that should be induced by an ideal vaccine to elicit effective, long-lasting protection. 
This review will address the current understanding of these viral epitope-BCR interactions and will consider the importance of a public $\mathrm{Ab}$ repertoire, which has been investigated in the context of other viruses but insufficiently studied in HCV. Developing a deeper understanding of these elements of the humoral response to $\mathrm{HCV}$ will provide key insights that will draw the goal of developing an effective vaccine nearer.

\section{HCV Envelope Epitopes and Immune Protection}

The HCV envelope glycoproteins E1 and E2 are the major targets of the neutralising $\mathrm{Ab}$ response, and as such, have been a key focus of research in recent years. In particular, the E2 protein plays a critical role in infection by binding to host entry factors, including CD81, scavenger receptor class B type 1 (SRB1), claudin1, occludin, Niemann-Pick C1-like 1 (NPC1L1), and several receptor tyrosine kinases [4]. Importantly, the binding of E2 to CD81 instigates the process of viral internalisation and, as such, the E2 binding sites for CD81 have been shown to be critical epitopes for neutralising activity [5]. Additionally, the hypervariable regions (HVRs) of E2 feature exceptionally high sequence variability and modulate the affinity and avidity of receptor binding and viral cell entry [6,7]. HVR1 has been of particular interest in recent years due to its proposed role in restricting the binding and activity of neutralising Abs (NAbs), likely by sterically masking key epitopes [8].

Several epitopes have been identified on E1 and E2 by independent groups, resulting in largely inconsistent nomenclature. The epitopes most widely referred to are the antigenic regions (ARs) 1-5, domains A-E and epitopes I-III (Figure 1). Amongst these incongruous epitope definitions lie several which largely overlap with one another, or even represent identical binding residues [9-11]. These residues are typically defined by alanine scanning mutagenesis (ASM) studies. Domains D and E, which form part of epitope I and epitope II, respectively, are predominantly linear, whereas most other epitopes that were similarly analysed were comprised of non-linear residues (Table 1, Figure 1) [9,12-17].

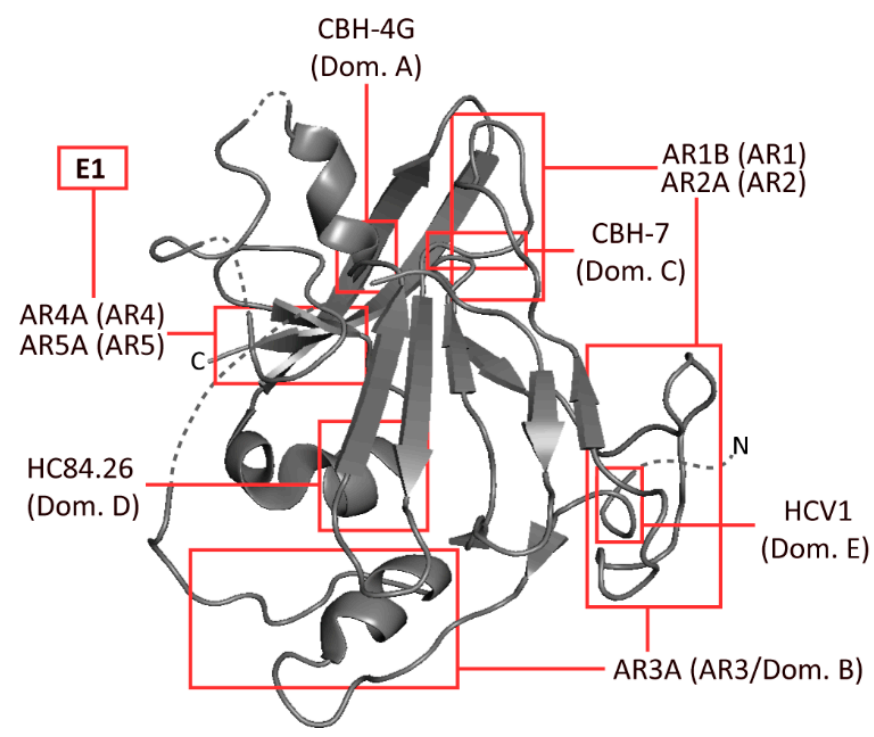

Figure 1. Schematic representation of HCV envelope protein E2, developed from the 2013 crystal structure of the protein by Kong et al. The approximate binding residues of nine mAbs covering a range of epitopes is shown. Structural information taken from the Protein Data Bank-accession code $4 \mathrm{MWF}$ [18]. 
Table 1. Common human mAbs specific to a range of HCV E2 (and E1) epitopes. Included are antigenic regions (1-5), as defined by Giang et al. [9]; and antigenic domains (A-E), as defined by Keck et al. [10]. Target epitope type was either conformational (C) or linear $(\mathrm{L})$. The binding residues indicate probable binding residues as assessed by alanine scanning mutagenesis (ASM). Neutralisation shown as the half-maximal inhibitory concentration ( $\mathrm{IC}_{50}$ ) of $\mathrm{H77}$.

\begin{tabular}{|c|c|c|c|c|c|}
\hline Ab Name & $\begin{array}{l}\text { Antigenic } \\
\text { Region }\end{array}$ & $\begin{array}{l}\text { Binding } \\
\text { Type }\end{array}$ & Binding Residues (Determined by ASM) & $\begin{array}{l}\text { Neutralisation } \\
\left(\mathrm{IC}_{50} \mu \mathrm{g} / \mathrm{mL}\right)\end{array}$ & References \\
\hline AR1A & 1 & $\mathrm{C}$ & $495,519,544,545,547,548,549,632$ & 5.7 & {$[12,19]$} \\
\hline AR1B & 1 & $\mathrm{C}$ & $\begin{array}{l}412,417,420-423,483-489,523-526 \\
530-532,534,538-540,544-549\end{array}$ & 0.06 & [12] \\
\hline AR2A & 2 & $\mathrm{C}$ & 625,628 & 0.47 & {$[12,19]$} \\
\hline AR3A & $3 / B$ & $\mathrm{C}$ & $\begin{array}{c}425,427-429,436-438,440-442,485,503 \\
518,520,529,530,535,616\end{array}$ & 0.5 & {$[12,19]$} \\
\hline A8 & 3/B & $\mathrm{C}$ & $523,529,530,535$ & 0.56 & {$[20]$} \\
\hline $\mathrm{CBH}-5$ & $3 / \mathrm{B}$ & $\mathrm{C}$ & $523,525,530,535,540$ & $0.04-13$ & {$[21,22]$} \\
\hline HC-1 & $3 / \mathrm{B}$ & $\mathrm{C}$ & $426,428,429,430,503,529,530,535$ & 0.16 & {$[19,23]$} \\
\hline AR4A & 4 & $\mathrm{C}$ & $\begin{array}{c}201,205,459,486,487,543,545,569,585 \\
594,597,652,677,679,698\end{array}$ & $0.03-38.5$ & {$[9,19]$} \\
\hline AR5A & 5 & $\mathrm{C}$ & $\begin{array}{c}201,205,459,486,513,543,569,585,594 \\
597,639,652,657,677,679\end{array}$ & 15 & {$[9,19]$} \\
\hline $\mathrm{CBH}-4 \mathrm{G}$ & A & $\mathrm{C}$ & $201,204-206$ & $>100$ & [13] \\
\hline CBH-7 & $\mathrm{C}$ & $\mathrm{C}$ & $544,545,547,549,597,626$ & 10 & {$[15,19]$} \\
\hline HC84.26 & $\mathrm{D}$ & $\mathrm{C}$ & $441,442,446,616$ & $0.005-12.91$ & {$[16,19]$} \\
\hline $\mathrm{HC} 84.27$ & $\mathrm{D}$ & $\mathrm{C}$ & $\begin{array}{c}425,426,428,429,441-443,446,530,536 \\
612,613,615\end{array}$ & $0.22-0.26$ & [16] \\
\hline HCV1 & E & $\mathrm{L}$ & $412-423$ & $0.15-15$ & {$[14,24]$} \\
\hline AP33 & E (mouse) & $\mathrm{L}$ & $412-423$ & $0.6-32$ & [25] \\
\hline MAb24 & E (mouse) & $\mathrm{L}$ & $411-428$ & 17.5 & [26] \\
\hline
\end{tabular}

\subsection{Variance in the Protection of Antibodies Directed at Distinct Epitopes}

The neutralising ability of mAbs generated against these various epitopes varies widely, with some epitopes typically inducing non-neutralising Abs, while others induce broad, strongly neutralising Abs. Most notably, AR3/domain B and AR4 epitopes have been shown repeatedly to induce bNAbs $[9,16]$, whereas Abs against domain A and AR1 Abs have been shown to have limited or no neutralisation ability. Domain C and AR2 often induce Abs with potent neutralisation activity; however, the Abs are often specific to unique viral genotypes [12,27]. Additionally, several studies have looked at the synergistic and interfering effects of two or more NAbs in combination. For example, it has been shown that epitope II-specific Abs can interfere with the neutralisation ability of epitope I-specific Abs [28]. More recent studies have analysed these combinatorial effects of several NAbs, identifying a wide range of synergies and interferences [29,30]. These findings suggest it may be beneficial to have a vaccine that can facilitate the induction of certain $\mathrm{Ab}$ specificities over others, with a focus on inducing multiple synergistic Abs with enhanced neutralisation breadth and potency. A contrasting approach was employed in a recent, proof-of-principle murine study, in which a bivalent vaccine was designed based on targeting residues with conserved physicochemical properties in the antigen (i.e., considering glycan and lipid shielding) rather than focusing on genetic variations. It was found that bNAbs were elicited which were active against $\mathrm{HCV}$ variants with up to $70 \%$ amino acid deviation from the immunogen sequences [31].

Furthermore, in a recent study, an alternate conformation of the E2 neutralising face was identified [32]. It was found that, upon binding by certain NAbs utilising the heavy chain $V_{H} 1-69$, which represents one of the most common and most heavily investigated $\mathrm{BCR}$ gene classes, the E2 front-layer region became displaced, exposing additional Abbinding epitopes, which may also be susceptible to neutralisation. More work needs to be done to comprehensively characterise these epitopes and the Abs which target them. 


\subsection{NAbs Targeting Hypervariable Region 1}

Hypervariable region 1 (HVR1) lies at the N-terminus of E2 and is incorporated as part of the AR3 epitope, among others. Following the identification of this region of high sequence diversity, its role in NAb recognition has been keenly explored. The development of technologies such as the HCV pseudoparticle (pp) and HCV cell culture (cc) systems allowed for the analysis of the impact of virus lacking HVR1 on NAb recognition. Initially, pseudoparticles with HVR1 removed ( $\triangle$ HVR1) were found to have an increased susceptibility to NAbs. Studies on humanised mice have suggested that HVR1 may partially mediate $\mathrm{Ab}$ resistance and contribute to viral persistence by protecting epitopes associated with neutralisation, conserved across multiple HCV genotypes [33]. These findings provoked a series of further studies characterising escape from NAbs mediated by HVR1, which showed that deleting or mutating HVR1 in HCV pseudoparticles (HCVpps) increased sensitivity to NAbs and made the HCVpps less infectious [34]. Recent studies have considered the use of $\triangle \mathrm{HVR} 1 \mathrm{E} 2$ in inducing bNAbs for vaccines; however, conclusions from these studies have not shown clear promise, with poor induction of cross-NAbs despite producing strong cross-binding Abs [35,36]. Conversely, a previous study found that when HVR1, HVR2 and the so-called intergenotypic variable region (igVR, also referred to as HVR3) were all simultaneously removed in a secreted E2 glycoprotein, protein folding and CD81 binding were not affected. However, when only one of these variable regions was deleted, infectivity was greatly reduced if not completely eliminated with a reduction in CD81 binding [37].

\subsection{Ab Immunodominance}

Immunodominance describes the relative abundance of Abs targeting specific epitopes of a given antigen across an antibody-positive (i.e., naturally exposed) population. By characterising the immunodominance of the response to epitopes associated with effective bNAbs, it becomes possible to understand which bNAbs are more readily induced by a wider population, which is critical information in the context of vaccine design. This is a research area that is only just beginning to be explored, with two very recent studies addressing the topic of $\mathrm{Ab}$ immunodominance in $\mathrm{HCV}[30,38]$. By defining the unique specificities within the polyclonal $\mathrm{Ab}$ responses in patients with acute $\mathrm{HCV}$ infection, the relationship between these specificities and the potency and breadth of neutralisation can be resolved. Although different panels of pseudoparticles and reference mAbs were used in these two studies, both reported that strong bNAb responses were enriched with broadly specific bNAbs directed towards AR3, AR4 and domain D. Moreover, there was no particular epitope associated with viral clearance, but rather Kinchen et al. indicated that viral clearance was associated with the presence of multiple NAbs targeting unique neutralising epitopes and reduced activity against non-neutralising domains $[30,38]$. The other of these two studies also suggested that the immunodominance profile may be influenced by the genotype of the virus (Figure 2) [30]. This suggests that the immunogenic profile of E1/E2 antigens from various viral genotypes should be assessed before selecting vaccine candidates. It should be noted that the induction of bNAbs is also likely to be influenced by the host immune repertoire, as discussed further below. 


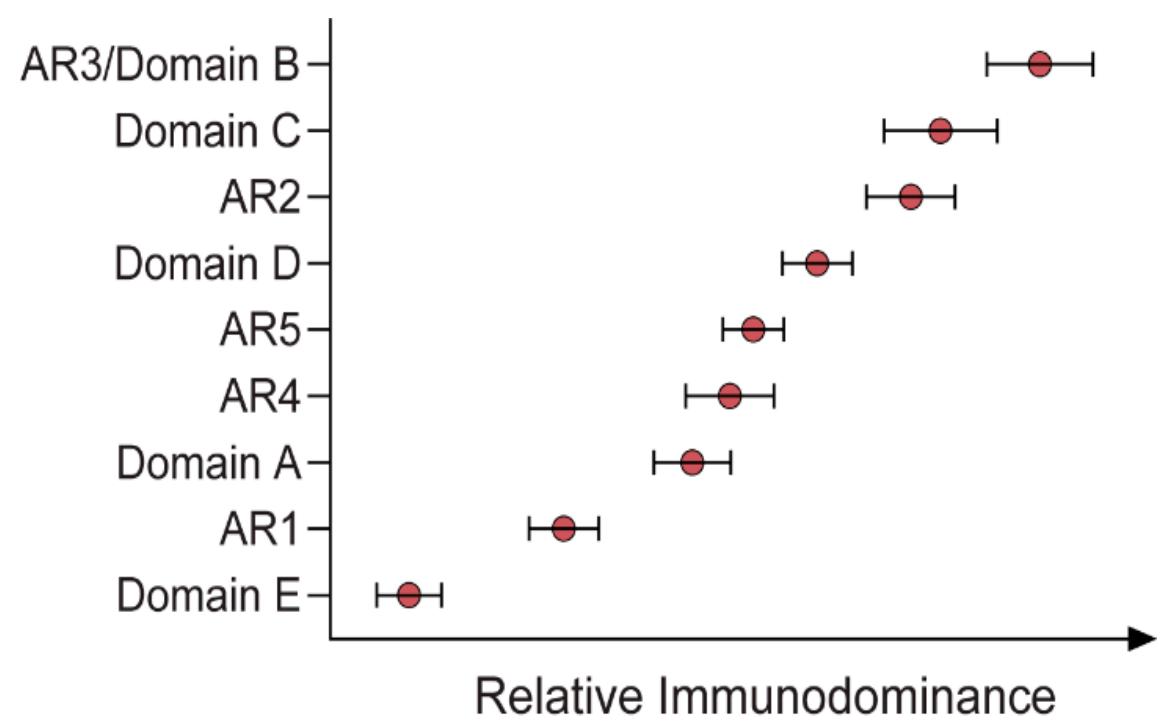

Figure 2. Relative immunodominance of Abs specific to antigenic regions (ARs) 1-5 and domains A-E of a GT1 viral envelope (H77) [30].

\section{The Interplay of HCV Infection and B-Cell Receptors (BCRs)}

Historically, the characterisation of the HCV-specific B-cell repertoire was limited to the examination of $\mathrm{B}$ cell clones isolated from the liver of patients with chronic $\mathrm{HCV}$ infection. Seminal studies in the early 1990s dissected the clonal perturbation of B cells within lymphoid aggregates or follicles, which are a common feature of the histopathology of chronic HCV infection, highlighting the presence of oligoclonal B cells, coining a now widely used term-HCV-driven clonal dominance [39]. Furthermore, early studies reinforced the idea of monoclonal or oligoclonal B-cell expansion in HCV-related chronic liver disease [39-43]. Prior to the single-cell sequencing era, Ab heavy $(\mathrm{H})$ chain variable, diversity and joining (VDJ) gene usage, as determined by polymerase chain reaction (PCR) and Sanger sequencing, was the primary method for B-cell clonal identification. Clonal expansion was indicated by dominant PCR bands, whereas a fully polyclonal pattern was identified by a smear with no specific dominant bands [39]. Its sensitivity depended upon the frequency of B cells present in the sample, often limiting accurate analysis. However, the identification of common B-cell $\mathrm{H}$ clonotypes (B cells that are derived from the same VDJ germline genes) highlighted the conserved structural and biochemical properties of the three complementarity-determining regions (CDRs) in antigen recognition [42]. These CDRs (CDR1, CDR2 and CDR3) lie within an Abs V region and are the sites of the greatest variability, determining specific $\mathrm{Ab}$ binding. In-depth analyses of the features of the $\mathrm{HCV}$-specific B-cell response and the association with the outcome of primary infection are limited, and studies analysing features of Abs isolated during acute HCV infection are rare. The landscape of B-cell repertoires, namely, specific $\mathrm{V}$ and $\mathrm{J}$ gene usage and conserved features of CDR2 and CDR3, has been reported by various studies, the majority of which utilised B-cell samples from chronic patients with co-morbidities such as mixed cryoglobulinemia [28] or lymphoma [39,44-49].

\section{Variable Region Immunoglobulin Heavy $\left(V_{H}\right)$ and Light $\left(V_{L}\right)$ Chain Gene Usage}

Over the last two decades, several studies have explored the idea that there may be a link between the pattern of particular Ab responses and VDJ gene usage against a range of pathogens [50]. It is theoretically predicted that approximately $10^{15}$ unique Abs can be generated through different VDJ recombination events, but how many of these theoretical clonotypes are present in an individual's Ab repertoire, particularly in the context of $\mathrm{HCV}$ infection, remains unknown [51]. Moreover, how much overlap in these repertoires exists between individuals (i.e., public clonotypes) is yet to be ascertained. In HCV, many of the bNAbs identified to date utilise the $\mathrm{V}_{\mathrm{H}} 1-69$ gene [52] and, encouragingly, have been 
isolated from patients that have spontaneously cleared single and multiple HCV infection events and only required limited somatic hypermutation (SHM) to achieve neutralising breadth [53,54]. $\mathrm{V}_{\mathrm{H}} 1-69$-derived Abs have also been shown to target a range of distinct epitopes, including domains B, C, D and those epitopes within HVR1 that may contribute to their broad neutralisation despite limited SHM [54].

$\mathrm{V}_{\mathrm{H}} 1-69$ is one of the more dominant gene classes present in the B-cell repertoire, and is commonly induced in viral infection [55]. One study that investigated the HCVspecific B-cell response in patients that cleared the virus and those who developed chronic infection indicated that $\mathrm{V}_{\mathrm{H}} 1-69$ Abs appeared to be at higher frequency in those with chronic infection, suggesting that this repertoire may be utilised only late in the course of chronic viraemia [56]. By contrast, in patients that cleared the virus, other antibodies

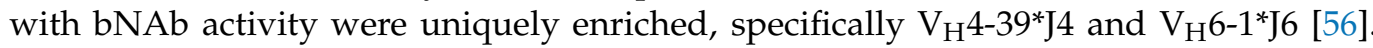
Overall, this study identified that $\mathrm{V}_{\mathrm{H}} 1, \mathrm{~V}_{\mathrm{H}} 3$ and $\mathrm{V}_{\mathrm{H}} 4$ gene families were common both in patients that cleared the virus and in those that developed chronic progressive disease. Another human study that used high-throughput sorting to a linear epitope (E2 residues 483-499) and single-cell sequencing also reported that $\mathrm{V}_{\mathrm{H}} 1, \mathrm{~V}_{\mathrm{H}} 3$ and $\mathrm{V}_{\mathrm{H}} 4$ were common in $\mathrm{HCV}$ infection, but no differences in $\mathrm{V}_{\mathrm{H}}$ gene usage were observed between disease outcome groups. In addition, this study also reported that $\mathrm{V}_{\mathrm{H}} 1-69$-derived antibodies, as opposed to $\mathrm{V}_{\mathrm{H}} 1-46-, \mathrm{V}_{\mathrm{H}} 3-15$ - and $\mathrm{V}_{\mathrm{H}} 3$-30-derived antibodies, were associated with higher neutralisation activity [57]. It is encouraging that a recent study using rhesus macaques as a model reported that similar gene usage to the human studies was preferentially expanded following immunisation with E1E2 [58]. These included $V_{H} 1-36, V_{H} 4-40$ and $V_{H} 5-7$, which are the human orthologs of $V_{H} 1-69, V_{H} 4-39$ and $V_{H} 5-57$, respectively. As in the second human study, in the rhesus macaques the $\mathrm{V}_{\mathrm{H}} 1$ antibodies generally displayed a higher neutralising capacity than the $\mathrm{V}_{\mathrm{H}} 4$ antibodies [58].

Interestingly, $\mathrm{V}_{\mathrm{H}} 1-69$ and $\mathrm{V}_{\mathrm{H}} 4-59$ are frequently expressed in B-cell disorders associated with chronic infection with $\mathrm{HCV}$, namely, mixed cryoglobulinemia and HCVassociated B-cell non-Hodgkin's lymphomas [45,59]. Patients with HCV-associated type II mixed cryoglobulinemia express Abs mostly encoded by germline $V_{\mathrm{H}} 1-69$ with biased use of the $V_{H} 1-69 / V_{k} A 27$ gene combination. This gene usage was also found in HCVassociated lymphomas, suggesting that they represent the malignant counterpart of type II mixed cryoglobulinemia [46]. The underlying mechanisms for these associations remain unknown, although it is plausible that they may be a consequence of molecular mimicry or lowering of the immune tolerance threshold due to a sustained hyper-inflamed state [60].

In light of the above, understanding how HCV infection and chronic co-morbidity might affect the generation and maintenance of HCV-specific BCRs is crucial for the rational design of an efficient therapeutic vaccine. Thus, it is imperative to understand the extent of immunoglobulin gene usage and development dynamics of antibody repertoires in order to advance vaccine development.

\section{An HCV Public Ab Repertoire}

Recently, large datasets of shared, or 'public', Ab repertoires in responses against different viral infections have been examined to define the typical distribution of Abs, with a particular focus on heavy and light variable gene usage, structure and CDR sequence. These studies include analysis in populations infected with HIV, influenza virus, Ebola virus, malaria, SARS-CoV-2 and HCV [61-67]. These studies report that the development of bNAbs is often restricted to certain $\mathrm{V}_{\mathrm{H}}$ gene usage and structure, and the relative abundance of these antibodies within the population and within the individuals' repertoire influences their induction.

One of the major challenges for HCV vaccine development has been the induction of an immune response with sufficient breadth to combat the large antigenic diversity of the $8 \mathrm{HCV}$ genotypes and 86 subtypes [68-70]. Longitudinal studies of natural infection suggest that neutralisation breadth often takes months or years to develop, with some studies indicating that subjects that clear the infection achieve greater breadth earlier [71]. 
For most bNAbs, key mutations are required to be introduced into the germline to reach breadth [72]. This has led to the concept of germline-targeting vaccines. For this approach to be effective, the targeted germline needs to be common across an ethnically diverse population and be sufficiently represented in the naïve repertoire to ensure it is 'engaged' by the vaccine.

A prominent example of this challenge is found in HIV, where it has been shown that, despite the identification of several potent bNAbs, only 10-38\% of those infected with HIV1 are able to generate Abs capable of broad cross-clade neutralisation [73,74]. In addition, many HIV bNAbs have distinctive features, including long CDR3 regions and high levels of SHM. In addition, the unmutated common ancestors often have a low precursor frequency and are not prevalent among subjects, making them difficult to target through vaccination. In HIV, it has been shown that immune tolerance mechanisms select against BCRs with long CDR3s due to their autoreactivity, resulting in a limited frequency in the naïve repertoire, a feature which has also been described for HCV AR3-like bNAbs [75]. Interestingly, in the HCV macaque study, a rapid contraction of the AR3-like $\mathrm{V}_{\mathrm{H}}$ 1-36 antibodies (human ortholog $\left.\mathrm{V}_{\mathrm{H}} 1-69\right)$ was observed following vaccination, suggesting that there would be value in the further exploration of human HCV studies [58].

The consensus interpretation of the HIV studies is that aiming for a vaccine which can induce a potent neutralising response may be unrealistic, and that, instead, a more reasonable goal would be to elicit a more moderately neutralising $\mathrm{Ab}$ response that is more readily produced among the at-risk population [76]. It has been suggested that focusing vaccine efforts on inducing 'public' antibody classes such as VRC01 [77] may be more efficient. VRC01-class antibodies commonly utilise a $\mathrm{V}_{\mathrm{H}} 1-2 * 02$ heavy chain, with key contacts identified within the CDR H2 and a CDR L3 of 5 amino acids. It is encouraging that a germline-targeting immunogen, eOD-GT8, has shown promise in being able to bind VRC01-class naïve B cells [78].

Similarly, promising work in influenza has indicated that a commonly induced class of neutralising antibodies targeting the haemagglutinin (HA) stem region can often be derived from the germline genes $\mathrm{V}_{\mathrm{H}} 1-69, \mathrm{~V}_{\mathrm{H}} 1-18$, and $\mathrm{V}_{\mathrm{H}} 6-1$ [79,80]. In malaria, a 'public' lineage derived from $\mathrm{V}_{\mathrm{H}} 3-30$ or $\mathrm{V}_{\mathrm{H}} 3-33$ and with potent neutralising activity was identified from multiple donors and indicated a promising pathway for a vaccine [81].

In HCV, AR3-specific antibodies share several structural and biophysical properties; they are preferentially encoded by $\mathrm{V}_{\mathrm{H}}$ 1-69 [82] and typically have a conserved hydrophobic pocket in CDRH2 and a long CDR3 loop. The induction of broadly neutralising antibodies encoded by $\mathrm{V}_{\mathrm{H}} 1-69$ has been associated with the natural clearance of HCV [83]. Studies in animal models suggest that E2 antigens can induce AR3-like antibodies with neutralising capacity after minimal SHM and are therefore of great interest [58]. Neutralising AR3like antibodies with $\mathrm{V}_{\mathrm{H}}$ 1-69 usage have also been isolated from clearers and chronic progressors, suggesting that they might be commonly available [18,84], although this has not been closely investigated across ethnic or geographic distributions. However, few studies have performed a detailed assessment of the human B-cell repertoire to HCV to assess how common these antibodies are in the population. Given the preference for longer CDR3s and studies in HIV suggesting that BCRs with long CDR3s may be selected against due to their auto-reactivity and are subsequently often present at lower frequencies in the repertoire, it would be useful to understand the frequency of HCV-specific bNAbs both in the repertoire, and between individuals. This knowledge would assist with understanding which antibodies may be more easily induced by vaccination.

Author Contributions: Conceptualisation: N.A.B. and R.A.B. Funding acquisition: R.A.B. and A.R.L. Investigation: N.A.B., A.A. and R.A.B. Supervision: R.A.B. and N.T. Visualization: N.A.B. Writingoriginal draft preparation: N.A.B. and A.A. Writing-review and editing: N.A.B., R.A.B., N.T. and A.R.L. All authors have read and agreed to the published version of the manuscript. 
Funding: The Kirby Institute is funded by the Australian Government Department of Health and Ageing. A.R.L. and R.A.B. are supported by NHMRC Research Fellowships (Numbers: 1137587 and 1084706).

Institutional Review Board Statement: Not applicable.

Informed Consent Statement: Not applicable.

Data Availability Statement: No new data were created or analysed in this study. Data sharing is not applicable to this article.

Conflicts of Interest: The authors declare no conflict of interest.

\section{References}

1. WHO. Hepatitis C; World Health Organization: Geneva, Switzerland, 2020.

2. WHO. Combating Hepatitis B and C to Reach Elimination by 2030; World Health Organization: Geneva, Switzerland, 2016.

3. Grebely, J.; Page, K.; Sacks-Davis, R.; van der Loeff, M.S.; Rice, T.M.; Bruneau, J.; Morris, M.D.; Hajarizadeh, B.; Amin, J.; Cox, A.L.; et al. The effects of female sex, viral genotype, and IL28B genotype on spontaneous clearance of acute hepatitis $C$ virus infection. Hepatology 2014, 59, 109-120. [CrossRef] [PubMed]

4. Fénéant, L.; Levy, S.; Cocquerel, L. CD81 and Hepatitis C Virus (HCV) Infection. Viruses 2014, 6, 535-572. [CrossRef] [PubMed]

5. Pileri, P.; Uematsu, Y.; Campagnoli, S.; Galli, G.; Falugi, F.; Petracca, R.; Weiner, A.J.; Houghton, M.; Rosa, D.; Grandi, G.; et al. Binding of Hepatitis C Virus to CD81. Science 1998, 282, 938-941. [CrossRef]

6. Bankwitz, D.; Steinmann, E.; Bitzegeio, J.; Ciesek, S.; Friesland, M.; Herrmann, E.; Zeisel, M.B.; Baumert, T.F.; Keck, Z.-Y.; Foung, S.K.H.; et al. Hepatitis C Virus Hypervariable Region 1 Modulates Receptor Interactions, Conceals the CD81 Binding Site, and Protects Conserved Neutralizing Epitopes. J. Virol. 2010, 84, 5751-5763. [CrossRef]

7. Forns, X.; Thimme, R.; Govindarajan, S.; Emerson, S.U.; Purcell, R.H.; Chisari, F.; Bukh, J. Hepatitis C virus lacking the hypervariable region 1 of the second envelope protein is infectious and causes acute resolving or persistent infection in chimpanzees. Proc. Natl. Acad. Sci. USA 2000, 97, 13318-13323. [CrossRef] [PubMed]

8. Prentoe, J.; Velázquez-Moctezuma, R.; Foung, S.K.H.; Law, M.; Bukh, J. Hypervariable region 1 shielding of hepatitis C virus is a main contributor to genotypic differences in neutralization sensitivity. Hepatology 2016, 64, 1881-1892. [CrossRef] [PubMed]

9. Giang, E.; Dorner, M.; Prentoe, J.C.; Dreux, M.; Evans, M.J.; Bukh, J.; Rice, C.M.; Ploss, A.; Burton, D.R.; Law, M. Human broadly neutralizing antibodies to the envelope glycoprotein complex of hepatitis C virus. Proc. Natl. Acad. Sci. USA 2012, 109, 6205-6210. [CrossRef] [PubMed]

10. Keck, Z.; Wang, W.; Wang, Y.; Lau, P.; Carlsen, T.H.R.; Prentoe, J.; Xia, J.; Patel, A.H.; Bukh, J.; Foung, S.K.H. Cooperativity in Virus Neutralization by Human Monoclonal Antibodies to Two Adjacent Regions Located at the Amino Terminus of Hepatitis C Virus E2 Glycoprotein. J. Virol. 2012, 87, 37-51. [CrossRef] [PubMed]

11. Drummer, H.E. Challenges to the development of vaccines to hepatitis C virus that elicit neutralizing antibodies. Front. Microbiol. 2014, 5, 329. [CrossRef]

12. Law, M.; Maruyama, T.; Lewis, J.T.; Giang, E.; Tarr, A.W.; Stamataki, Z.; Gastaminza, P.; Chisari, F.; Jones, I.M.; I Fox, R.; et al. Broadly neutralizing antibodies protect against hepatitis C virus quasispecies challenge. Nat. Med. 2008, 14, 25-27. [CrossRef]

13. Keck, Z.-Y.; De Beeck, A.O.; Hadlock, K.G.; Xia, J.; Li, T.-K.; Dubuisson, J.; Foung, S.K.H. Hepatitis C Virus E2 Has Three Immunogenic Domains Containing Conformational Epitopes with Distinct Properties and Biological Functions. J. Virol. 2004, 78, 9224-9232. [CrossRef] [PubMed]

14. Broering, T.J.; Garrity, K.A.; Boatright, N.K.; Sloan, S.E.; Sandor, F.; Thomas, W.D.; Szabo, G.; Finberg, R.W.; Ambrosino, D.M.; Babcock, G.J. Identification and Characterization of Broadly Neutralizing Human Monoclonal Antibodies Directed against the E2 Envelope Glycoprotein of Hepatitis C Virus. J. Virol. 2009, 83, 12473-12482. [CrossRef]

15. Hadlock, K.G.; Lanford, R.E.; Perkins, S.; Rowe, J.; Yang, Q.; Levy, S.; Pileri, P.; Abrignani, S.; Foung, S.K.H. Human Monoclonal Antibodies That Inhibit Binding of Hepatitis C Virus E2 Protein to CD81 and Recognize Conserved Conformational Epitopes. J. Virol. 2000, 74, 10407-10416. [CrossRef] [PubMed]

16. Keck, Z.-Y.; Xia, J.; Wang, Y.; Wang, W.; Krey, T.; Prentoe, J.; Carlsen, T.; Li, A.Y.-J.; Patel, A.H.; Lemon, S.M.; et al. Human Monoclonal Antibodies to a Novel Cluster of Conformational Epitopes on HCV E2 with Resistance to Neutralization Escape in a Genotype 2a Isolate. PLoS Pathog. 2012, 8, e1002653. [CrossRef] [PubMed]

17. Sautto, G.A.; Tarr, A.W.; Mancini, N.; Clementi, M. Structural and Antigenic Definition of Hepatitis C Virus E2 Glycoprotein Epitopes Targeted by Monoclonal Antibodies. Clin. Dev. Immunol. 2013, 2013, 450963. [CrossRef] [PubMed]

18. Kong, L.; Giang, E.; Nieusma, T.; Kadam, R.U.; Cogburn, K.E.; Hua, Y.; Dai, X.; Stanfield, R.L.; Burton, D.R.; Ward, A.B.; et al. Hepatitis C Virus E2 Envelope Glycoprotein Core Structure. Science 2013, 342, 1090-1094. [CrossRef]

19. Kinchen, V.J.; Cox, A.L.; Bailey, J.R. Can Broadly Neutralizing Monoclonal Antibodies Lead to a Hepatitis C Virus Vaccine? Trends Microbiol. 2018, 26, 854-864. [CrossRef]

20. Johansson, D.X.; Voisset, C.; Tarr, A.W.; Aung, M.; Ball, J.K.; Dubuisson, J.; Persson, M.A.A. Human combinatorial libraries yield rare antibodies that broadly neutralize hepatitis C virus. Proc. Natl. Acad. Sci. USA 2007, 104, 16269-16274. [CrossRef] 
21. Owsianka, A.M.; Tarr, A.W.; Keck, Z.-Y.; Li, T.-K.; Witteveldt, J.; Adair, R.; Foung, S.K.H.; Ball, J.K.; Patel, A.H. Broadly neutralizing human monoclonal antibodies to the hepatitis C virus E2 glycoprotein. J. Gen. Virol. 2008, 89, 653-659. [CrossRef]

22. Keck, Z.-Y.; Xia, J.; Cai, Z.; Li, T.-K.; Owsianka, A.M.; Patel, A.H.; Luo, G.; Foung, S.K.H. Immunogenic and Functional Organization of Hepatitis C Virus (HCV) Glycoprotein E2 on Infectious HCV Virions. J. Virol. 2006, 81, 1043-1047. [CrossRef]

23. Wang, Y.; Keck, Z.-Y.; Saha, A.; Xia, J.; Conrad, F.; Lou, J.; Eckart, M.; Marks, J.D.; Foung, S.K.H. Affinity Maturation to Improve Human Monoclonal Antibody Neutralization Potency and Breadth against Hepatitis C Virus. J. Biol. Chem. 2011, 286, 44218-44233. [CrossRef] [PubMed]

24. Center, R.J.; Boo, I.; Phu, L.; McGregor, J.; Poumbourios, P.; Drummer, H.E. Enhancing the antigenicity and immunogenicity of monomeric forms of hepatitis C virus E2 for use as a preventive vaccine. J. Biol. Chem. 2020, 295, 7179-7192. [CrossRef]

25. Owsianka, A.; Tarr, A.W.; Juttla, V.S.; Lavillette, D.; Bartosch, B.; Cosset, F.-L.; Ball, J.K.; Patel, A.H. Monoclonal Antibody AP33 Defines a Broadly Neutralizing Epitope on the Hepatitis C Virus E2 Envelope Glycoprotein. J. Virol. 2005, 79, 11095-11104. [CrossRef] [PubMed]

26. Alhammad, Y.M.; Gu, J.; Boo, I.; Harrison, D.N.; McCaffrey, K.; Vietheer, P.T.; Edwards, S.; Quinn, C.; Coulibaly, F.; Poumbourios, P.; et al. Monoclonal Antibodies Directed toward the Hepatitis C Virus Glycoprotein E2 Detect Antigenic Differences Modulated by the N-Terminal Hypervariable Region 1 (HVR1), HVR2, and Intergenotypic Variable Region. J. Virol. 2015, 89, 12245-12261. [CrossRef] [PubMed]

27. Carlsen, T.H.; Pedersen, J.; Prentoe, J.C.; Giang, E.; Keck, Z.-Y.; Mikkelsen, L.S.; Law, M.; Foung, S.K.; Bukh, J. Breadth of neutralization and synergy of clinically relevant human monoclonal antibodies against HCV genotypes 1a, 1b, 2a, 2b, 2c, and 3a. Hepatology 2014, 60, 1551-1562. [CrossRef]

28. Kachko, A.V.; Frey, S.E.; Sirota, L.; Ray, R.; Wells, F.; Zubkova, I.; Zhang, P.; Major, M.E. Antibodies to an interfering epitope in hepatitis $C$ virus E2 can mask vaccine-induced neutralizing activity. Hepatology 2015, 62, 1670-1682. [CrossRef] [PubMed]

29. Mankowski, M.C.; Kinchen, V.J.; Wasilewski, L.N.; Flyak, A.I.; Ray, S.C.; Crowe, J.E.; Bailey, J.R. Synergistic anti-HCV broadly neutralizing human monoclonal antibodies with independent mechanisms. Proc. Natl. Acad. Sci. USA 2018, 115, E82-E91. [CrossRef] [PubMed]

30. Brasher, N.A.; Eltahla, A.A.; Underwood, A.; Boo, I.; Rizzetto, S.; Walker, M.R.; Rodrigo, C.; Luciani, F.; Maher, L.; Drummer, H.E.; et al. B cell immunodominance in primary hepatitis $C$ virus infection. J. Hepatol. 2020, 72, 670-679. [CrossRef]

31. Mosa, A.I.; Urbanowicz, R.A.; AbouHaidar, M.G.; Tavis, J.E.; Ball, J.K.; Feld, J.J. A bivalent HCV peptide vaccine elicits pan-genotypic neutralizing antibodies in mice. Vaccine 2020, 38, 6864-6867. [CrossRef]

32. Tzarum, N.; Giang, E.; Kadam, R.U.; Chen, F.; Nagy, K.; Augestad, E.H.; Velázquez-Moctezuma, R.; Keck, Z.-Y.; Hua, Y.; Stanfield, R.L.; et al. An alternate conformation of HCV E2 neutralizing face as an additional vaccine target. Sci. Adv. 2020, 6, eabb5642. [CrossRef]

33. Prentoe, J.; Verhoye, L.; Moctezuma, R.V.; Buysschaert, C.; Farhoudi, A.; Wang, R.; Alter, H.J.; Meuleman, P.; Bukh, J. HVR1mediated antibody evasion of highly infectious In Vivo adapted HCV in humanised mice. Gut 2016, 65, 1988-1997. [CrossRef]

34. Bartosch, B.; Verney, G.; Dreux, M.; Donot, P.; Morice, Y.; Penin, F.; Pawlotsky, J.-M.; Lavillette, D.; Cosset, F.-L. An Interplay between Hypervariable Region 1 of the Hepatitis C Virus E2 Glycoprotein, the Scavenger Receptor BI, and High-Density Lipoprotein Promotes both Enhancement of Infection and Protection against Neutralizing Antibodies. J. Virol. 2005, 79, 8217-8229. [CrossRef] [PubMed]

35. Khera, T.; Behrendt, P.; Bankwitz, D.; Brown, R.J.; Todt, D.; Doepke, M.; Khan, A.G.; Schulze, K.; Law, J.; Logan, M.; et al. Functional and immunogenic characterization of diverse HCV glycoprotein E2 variants. J. Hepatol. 2019, 70, 593-602. [CrossRef] [PubMed]

36. Law, J.L.M.; Logan, M.; Wong, J.; Kundu, J.; Hockman, D.; Landi, A.; Chen, C.; Crawford, K.; Wininger, M.; Johnson, J.; et al. Role of the E2 Hypervariable Region (HVR1) in the Immunogenicity of a Recombinant Hepatitis C Virus Vaccine. J. Virol. 2018, 92. [CrossRef] [PubMed]

37. McCaffrey, K.; Gouklani, H.; Boo, I.; Poumbourios, P.; Drummer, H.E. The variable regions of hepatitis C virus glycoprotein E2 have an essential structural role in glycoprotein assembly and virion infectivity. J. Gen. Virol. 2010, 92, 112-121. [CrossRef]

38. Kinchen, V.J.; Massaccesi, G.; Flyak, A.I.; Mankowski, M.C.; Colbert, M.D.; Osburn, W.O.; Ray, S.C.; Cox, A.L.; Jr, J.E.C.; Bailey, J.R. Plasma deconvolution identifies broadly neutralizing antibodies associated with hepatitis $C$ virus clearance. J. Clin. Investig. 2019, 129, 4786-4796. [CrossRef]

39. Sansonno, D.; de Vita, S.; Iacobelli, A.R.; Cornacchiulo, V.; Boiocchi, M.; Dammacco, F. Clonal analysis of intrahepatic B cells from HCV-infected patients with and without mixed cryoglobulinemia. J. Immunol. 1998, 160, 3594-3601. [PubMed]

40. Dammacco, F.; Gatti, P.; Sansonno, D. Hepatitis C Virus Infection, Mixed Cryoglobulinemia, and Non-Hodgkin's Lymphoma: An Emerging Picture. Leuk. Lymphoma 1998, 31, 463-476. [CrossRef] [PubMed]

41. Vallat, L.; Benhamou, Y.; Gutierrez, M.; Ghillani, P.; Hercher, C.; Thibault, V.; Charlotte, F.; Piette, J.C.; Poynard, T.; Merle-Béral, H.; et al. Clonal B cell populations in the blood and liver of patients with chronic hepatitis C virus infection. Arthritis Rheum. 2004, 50, 3668-3678. [CrossRef]

42. Racanelli, V.; Sansonno, D.; Piccoli, C.; D’Amore, F.P.; Tucci, F.A.; Dammacco, F. Molecular Characterization of B Cell Clonal Expansions in the Liver of Chronically Hepatitis C Virus-Infected Patients. J. Immunol. 2001, 167, 21-29. [CrossRef] [PubMed]

43. Magalini, A.R.; Facchetti, F.; Salvi, L.; Fontana, L.; Puoti, M.; Scarpa, A. Clonality of B-cells in portal lymphoid infiltrates of HCV-infected livers. J. Pathol. 1998, 185, 86-90. [CrossRef] 
44. Marasca, R.; Vaccari, P.; Luppi, M.; Zucchini, P.; Castelli, I.; Barozzi, P.; Cuoghi, A.; Torelli, G. Immunoglobulin Gene Mutations and Frequent Use of VH1-69 and VH4-34 Segments in Hepatitis C Virus-Positive and Hepatitis C Virus-Negative Nodal Marginal Zone B-Cell Lymphoma. Am. J. Pathol. 2001, 159, 253-261. [CrossRef]

45. Ivanovski, M.; Silvestri, F.; Pozzato, G.; Anand, S.; Mazzaro, C.; Burrone, O.R.; Efremov, D.G. Somatic hypermutation, clonal diversity, and preferential expression of the VH 51p1/VL kv325 immunoglobulin gene combination in hepatitis C virus-associated immunocytomas. Blood 1998, 91, 2433-2442. [CrossRef] [PubMed]

46. Chan, C.H.; Hadlock, K.G.; Foung, S.K.H.; Levy, S. VH1-69 gene is preferentially used by hepatitis C virus-associated B cell lymphomas and by normal B cells responding to the E2 viral antigen. Blood 2001, 97, 1023-1026. [CrossRef] [PubMed]

47. Johnson, T.A.; Rassenti, L.Z.; Kipps, T.J. Ig VH1 genes expressed in B cell chronic lymphocytic leukemia exhibit distinctive molecular features. J. Immunol. 1997, 158, 235-246.

48. Wu, Y.-C.B.; Kipling, D.; Leong, H.S.; Martin, V.; Ademokun, A.A.; Dunn-Walters, D.K. High-throughput immunoglobulin repertoire analysis distinguishes between human IgM memory and switched memory B-cell populations. Blood 2010, 116, 1070-1078. [CrossRef] [PubMed]

49. Quinn, E.R.; Chan, C.H.; Hadlock, K.G.; Foung, S.K.H.; Flint, M.; Levy, S. The B-cell receptor of a hepatitis C virus (HCV)associated non-Hodgkin lymphoma binds the viral E2 envelope protein, implicating HCV in lymphomagenesis. Blood 2001, 98, 3745-3749. [CrossRef]

50. Brezinschek, H.P.; Brezinschek, R.I.; Lipsky, P.E. Analysis of the heavy chain repertoire of human peripheral B cells using single-cell polymerase chain reaction. J. Immunol. 1995, 155, 190-202.

51. Elhanati, Y.; Sethna, Z.; Marcou, Q.; Callan, C.G., Jr.; Mora, T.; Walczak, A.M. Inferring processes underlying B-cell repertoire diversity. Philos. Trans. R. Soc. B Biol. Sci. 2015, 370, 20140243. [CrossRef] [PubMed]

52. Colbert, M.D.; Flyak, A.I.; Ogega, C.O.; Kinchen, V.J.; Massaccesi, G.; Hernandez, M.; Davidson, E.; Doranz, B.J.; Cox, A.L.; Crowe, J.; et al. Broadly Neutralizing Antibodies Targeting New Sites of Vulnerability in Hepatitis C Virus E1E2. J. Virol. 2019, 93, 14. [CrossRef]

53. Bailey, J.R.; Flyak, A.I.; Cohen, V.J.; Li, H.; Wasilewski, L.N.; Snider, A.E.; Wang, S.; Learn, G.H.; Kose, N.; Loerinc, L.; et al. Broadly neutralizing antibodies with few somatic mutations and hepatitis C virus clearance. JCI Insight 2017, 2, 9. [CrossRef]

54. Keck, Z.-Y.; Pierce, B.G.; Lau, P.; Lu, J.; Wang, Y.; Underwood, A.; Bull, R.A.; Prentoe, J.; Velázquez-Moctezuma, R.; Walker, M.R.; et al. Broadly neutralizing antibodies from an individual that naturally cleared multiple hepatitis $C$ virus infections uncover molecular determinants for E2 targeting and vaccine design. PLoS Pathog. 2019, 15, e1007772. [CrossRef] [PubMed]

55. Chen, F.; Tzarum, N.; A Wilson, I.; Law, M. VH1-69 antiviral broadly neutralizing antibodies: Genetics, structures, and relevance to rational vaccine design. Curr. Opin. Virol. 2019, 34, 149-159. [CrossRef] [PubMed]

56. Eliyahu, S.; Sharabi, O.; Elmedvi, S.; Timor, R.; Davidovich, A.; Vigneault, F.; Clouser, C.; Hope, R.; Nimer, A.; Braun, M.; et al. Antibody Repertoire Analysis of Hepatitis C Virus Infections Identifies Immune Signatures Associated with Spontaneous Clearance. Front. Immunol. 2018, 9, 3004. [CrossRef] [PubMed]

57. Olbrich, A.; Wardemann, H.; Bohm, S.; Rother, K.; Colpitts, C.C.; Wrensch, F.; Baumert, T.F.; Berg, T.; Benckert, J. Repertoire and Neutralizing Activity of Antibodies Against Hepatitis C Virus E2 Peptide in Patients with Spontaneous Resolution of Hepatitis C. J. Infect. Dis. 2019, 220, 1209-1218. [CrossRef]

58. Chen, F.; Tzarum, N.; Lin, X.; Giang, E.; Velázquez-Moctezuma, R.; Augestad, E.H.; Nagy, K.; He, L.; Hernandez, M.; Fouch, M.E.; et al. Functional convergence of a germline-encoded neutralizing antibody response in rhesus macaques immunized with $\mathrm{HCV}$ envelope glycoproteins. Immunity 2021, 54, 781-796.e4. [CrossRef]

59. Charles, E.D.; Green, R.M.; Marukian, S.; Talal, A.H.; Lake-Bakaar, G.V.; Jacobson, I.M.; Rice, C.M.; Dustin, L.B. Clonal expansion of immunoglobulin M+CD27+ B cells in HCV-associated mixed cryoglobulinemia. Blood 2008, 111, 1344-1356. [CrossRef]

60. Roughan, J.E.; Reardon, K.M.; Cogburn, K.E.; Quendler, H.; Pockros, P.J.; Law, M. Chronic Hepatitis C Virus Infection Breaks Tolerance and Drives Polyclonal Expansion of Autoreactive B Cells. Clin. Vaccine Immunol. 2012, 19, 1027-1037. [CrossRef]

61. Imkeller, K.; Wardemann, H. Assessing human B cell repertoire diversity and convergence. Immunol. Rev. 2018, 284, 51-66. [CrossRef]

62. Guo, K.; Halemano, K.; Schmitt, K.; Katuwal, M.; Wang, Y.; Harper, M.S.; Heilman, K.J.; Kuwata, T.; Stephens, E.B.; Santiago, M.L. Immunoglobulin VH gene diversity and somatic hypermutation during SIV infection of rhesus macaques. Immunogenetics 2015, 67, 355-370. [CrossRef]

63. Patera, A.C.; Graham, C.M.; Thomas, D.B.; Smith, C.A. Immunodominance with progenitor B cell diversity in the neutralizing antibody repertoire to influenza infection. Eur. J. Immunol. 1995, 25, 1803-1809. [CrossRef]

64. Wang, B.; Kluwe, C.A.; Lungu, O.I.; DeKosky, B.J.; Kerr, S.A.; Johnson, E.L.; Tanno, H.; Lee, C.-H.; Jung, J.; Rezigh, A.B.; et al. Facile Discovery of a Diverse Panel of Anti-Ebola Virus Antibodies by Immune Repertoire Mining. Sci. Rep. 2015, 5. [CrossRef]

65. Racanelli, V.; Brunetti, C.; de Re, V.; Caggiari, L.; de Zorzi, M.; Leone, P.; Perosa, F.; Vacca, A.; Dammacco, F. Antibody V(h) repertoire differences between resolving and chronically evolving hepatitis C virus infections. PLoS ONE 2011, 6, e25606. [CrossRef] [PubMed]

66. Robbiani, D.F.; Gaebler, C.; Muecksch, F.; Lorenzi, J.C.C.; Wang, Z.; Cho, A.; Agudelo, M.; Barnes, C.O.; Gazumyan, A.; Finkin, S.; et al. Convergent antibody responses to SARS-CoV-2 in convalescent individuals. Nature 2020, 584, 437-442. [CrossRef] [PubMed] 
67. Nielsen, S.C.A.; Yang, F.; Jackson, K.J.L.; Hoh, R.A.; Roltgen, K.; Jean, G.H.; Stevens, B.A.; Lee, J.Y.; Rustagi, A.; Rogers, A.J.; et al. Human B Cell Clonal Expansion and Convergent Antibody Responses to SARS-CoV-2. Cell Host Microbe 2020, 28, 516-525.e5. [CrossRef] [PubMed]

68. Borgia, S.M.; Hedskog, C.; Parhy, B.; Hyland, R.H.; Stamm, L.M.; Brainard, D.M.; Subramanian, M.G.; McHutchison, J.G.; Mo, H.; Svarovskaia, E.; et al. Identification of a Novel Hepatitis C Virus Genotype from Punjab, India: Expanding Classification of Hepatitis C Virus Into 8 Genotypes. J. Infect. Dis. 2018, 218, 1722-1729. [CrossRef] [PubMed]

69. Salmona, M.; Caporossi, A.; Simmonds, P.; Thélu, M.-A.; Fusillier, K.; Mercier-Delarue, S.; De Castro, N.; LeGoff, J.; Chaix, M.-L.; François, O; et al. First next-generation sequencing full-genome characterization of a hepatitis $\mathrm{C}$ virus genotype 7 divergent subtype. Clin. Microbiol. Infect. 2016, 22, 947.e1-947.e8. [CrossRef]

70. Hedskog, C.; Parhy, B.; Chang, S.; Zeuzem, S.; Moreno, C.; Shafran, S.D.; Borgia, S.M.; Asselah, T.; Alric, L.; Abergel, A.; et al. Identification of 19 Novel Hepatitis C Virus Subtypes-Further Expanding HCV Classification. Open Forum Infect. Dis. 2019, 6, ofz076. [CrossRef] [PubMed]

71. Osburn, W.O.; Snider, A.E.; Wells, B.L.; Latanich, R.; Bailey, J.R.; Thomas, D.L.; Cox, A.L.; Ray, S.C. Clearance of hepatitis C infection is associated with the early appearance of broad neutralizing antibody responses. Hepatology 2014, 59, $2140-2151$. [CrossRef]

72. Kwong, P.D.; Mascola, J.R. HIV-1 Vaccines Based on Antibody Identification, B Cell Ontogeny, and Epitope Structure. Immunity 2018, 48, 855-871. [CrossRef]

73. Binley, J.M.; Lybarger, E.A.; Crooks, E.T.; Seaman, M.S.; Gray, E.; Davis, K.L.; Decker, J.M.; Wycuff, D.; Harris, L.; Hawkins, N.; et al. Profiling the Specificity of Neutralizing Antibodies in a Large Panel of Plasmas from Patients Chronically Infected with Human Immunodeficiency Virus Type 1 Subtypes B and C. J. Virol. 2008, 82, 11651-11668. [CrossRef] [PubMed]

74. Doria-Rose, N.A.; Klein, R.M.; Manion, M.M.; O’Dell, S.; Phogat, A.; Chakrabarti, B.; Hallahan, C.W.; Migueles, S.A.; Wrammert, J.; Ahmed, R.; et al. Frequency and Phenotype of Human Immunodeficiency Virus Envelope-Specific B Cells from Patients with Broadly Cross-Neutralizing Antibodies. J. Virol. 2008, 83, 188-199. [CrossRef] [PubMed]

75. Zhang, R.; Verkoczy, L.; Wiehe, K.; Alam, S.M.; Nicely, N.I.; Santra, S.; Bradley, T.; Pemble, C.W.; Zhang, J.; Gao, F.; et al. Initiation of immune tolerance-controlled HIV gp41 neutralizing B cell lineages. Sci. Transl. Med. 2016, 8, 336ra62. [CrossRef] [PubMed]

76. Hraber, P.; Seaman, M.S.; Bailer, R.T.; Mascola, J.R.; Montefiori, D.C.; Korber, B.T. Prevalence of broadly neutralizing antibody responses during chronic HIV-1 infection. AIDS 2014, 28, 163-169. [CrossRef] [PubMed]

77. Zhou, T.; Zhu, J.; Wu, X.; Moquin, S.; Zhang, B.; Acharya, P.; Georgiev, I.S.; Altae-Tran, H.R.; Chuang, G.-Y.; Joyce, M.G.; et al. Multidonor Analysis Reveals Structural Elements, Genetic Determinants, and Maturation Pathway for HIV-1 Neutralization by VRC01-Class Antibodies. Immunity 2013, 39, 245-258. [CrossRef] [PubMed]

78. Jardine, J.G.; Kulp, D.W.; Havenar-Daughton, C.; Sarkar, A.; Briney, B.; Sok, D.; Sesterhenn, F.; Ereño-Orbea, J.; Kalyuzhniy, O.; Deresa, I.; et al. HIV-1 broadly neutralizing antibody precursor B cells revealed by germline-targeting immunogen. Science 2016, 351, 1458-1463. [CrossRef] [PubMed]

79. Kallewaard, N.L.; Corti, D.; Collins, P.J.; Neu, U.; McAuliffe, J.M.; Benjamin, E.; Wachter-Rosati, L.; Palmer-Hill, F.J.; Yuan, A.Q.; Walker, P.A.; et al. Structure and Function Analysis of an Antibody Recognizing All Influenza A Subtypes. Cell 2016, 166, 596-608. [CrossRef]

80. Lingwood, D.; McTamney, P.M.; Yassine, H.M.; Whittle, J.R.R.; Guo, X.; Boyington, J.C.; Wei, C.-J.; Nabel, G.J. Structural and genetic basis for development of broadly neutralizing influenza antibodies. Nat. Cell Biol. 2012, 489, 566-570. [CrossRef]

81. Tan, J.; Sack, B.K.; Oyen, D.; Zenklusen, I.; Piccoli, L.; Barbieri, S.; Foglierini, M.; Fregni, C.S.; Marcandalli, J.; Jongo, S.; et al. A public antibody lineage that potently inhibits malaria infection through dual binding to the circumsporozoite protein. Nat. Med. 2018, 24, 401-407. [CrossRef]

82. Tzarum, N.; Giang, E.; Kong, L.; He, L.; Prentoe, J.; Augestad, E.; Hua, Y.; Castillo, S.; Lauer, G.M.; Bukh, J.; et al. Genetic and structural insights into broad neutralization of hepatitis $\mathrm{C}$ virus by human $\mathrm{V}(\mathrm{H}) 1-69$ antibodies. Sci. Adv. 2019, 5, eaav1882. [CrossRef]

83. Bailey, J.R.; Wasilewski, L.N.; Snider, A.E.; El-Diwany, R.; Osburn, W.O.; Keck, Z.; Foung, S.K.; Ray, S.C. Naturally selected hepatitis $C$ virus polymorphisms confer broad neutralizing antibody resistance. J. Clin. Investig. 2015, 125, 437-447. [CrossRef] [PubMed]

84. Freedman, H.; Logan, M.R.; Law, J.L.M.; Houghton, M. Structure and Function of the Hepatitis C Virus Envelope Glycoproteins E1 and E2: Antiviral and Vaccine Targets. ACS Infect. Dis. 2016, 2, 749-762. [CrossRef] [PubMed] 